\title{
Anyakőzet-tulajdonságok és termikus átalakulások a Kösseni Formációban
}

\author{
KoNCZ István
}

koncz.istvan38@gmail.com

\section{Source rock features and thermal transformations in the Kössen Formation}

\begin{abstract}
According to the results of oil-to-source rock correlation, heavy oils discovered in Nagylengyel were generated by the Kössen Formation. Based on trend values of Rock-Eval data and organic sulfur to carbon-atomic ratios, the lower part of the Kössen Formation in the Rezi-1 drilling shows high hydrocarbon potential and the presence of sulfur-rich, type IIS kerogen.

Using the hypothetical burial history of the Kössen Formation in the Bak-Nova trench and kinetic constants corresponding to IIS kerogen, thermal transformation generating heavy oil came to an end in Upper Cretaceous at a temperature of $70^{\circ} \mathrm{C}$. This early generation of oil was due to the presence of sulfur-rich, IIS type kerogen.

The primary migration of heavy oil caused by overpressure coincides with the beginning of decomposition of asphaltenes present in the heavy oil. Micro-fracturing of the Kössen Formation was due to the volume increase of oil present in the pores, itself being the consequence of asphaltene decomposition.

Thermal transformation of kerogen in the Kössen Formation ended with gas generation at higher maturity levels corresponding to vitrinite reflectance of at least $1.3 \%$.
\end{abstract}

Keywords: IIS type kerogen, heavy oil, asphaltene decomposition, primary migration

\section{Összefoglalás}

Az olaj-anyakőzet korrelációk eredményei szerint a Nagylengyelben felfedezett nehézolajat a Kösseni Formáció generálta. A Rock-Eval adatok és a szerves kén-szén atomarányok alapján a Kösseni Formáció alsó része a Rezi-1 fúrásban magas szénhidrogén-potenciálú és a kénben dús, IIS típusú kerogén jelenlétét mutatja.

Felhasználva a Bak-Nova-árokban lévő Kösseni Formáció feltételezett eltemetődési történetét és a IIS típusú kerogénnek megfelelő kinetikai konstansokat, a nehézolaj képződése a felső kréta időszakban, $70^{\circ} \mathrm{C}$ hőmérsékleten ért véget. Az olaj ilyen korai képződése kénben dús, IIS típusú kerogén jelenlétének köszönhetô.

A nehézolajnak a túlnyomás által létrehozott primer migrációja egybeesik a nehézolajban lévő aszfaltének bomlása kezdetével. A Kösseni Formáció felrepedése a pórusokban jelen lévő olaj térfogat-növekedése miatt előállt nyomásnövekedésnek köszönhetô, ami az aszfaltén-bomlás következménye.

A Kösseni Formáció kerogénjének termikus átalakulása gázképződéssel zárul a legalább 1,3\% vitrinitreflexiónak megfelelő magasabb termikus érettségi szinteken.

Kulcsszavak: IIS típusú kerogén, nehézolaj, aszfaltén-bomlás, primer migráció

\section{Bevezetés}

Ez idő szerint a felsô triász korú Kösseni Formáció Magyarország legidősebb anyakôzzete, amely felhalmozódásokat hozott létre Nagylengyel térségében. Az észak-zalai medence fejlődéstörténete a következőkben vázolható (DubAY 1962). A telepek a felső triász (nori) Fődolomitban és a felső kréta (rudistás) mészkőben helyezkednek el, amelyekben fốleg karsztos üregek tartalmazzák az olajat. Az orogén fázisok alatt mind a Fődolomit, mind a felső kréta mészkô felszíne szárazulattá vált, és karsztosodott. Az ausztriai orogén fázis idején, a kréta időszakban az alsó kréta és a jura korú üledékek eróziót szenvedtek, ső́t - a szerkezet Ny-i részén - a felső triász Kösseni Formáció is megsem- 
misült: a nyugati részen lévő Salomvár jelû fúrásokban a Fődolomit közvetlenül a miocén üledékekkel érintkezik. A későbbi, larami és pireneusi orogén fázisok során alakultak ki a felső kréta rudistás mészkő karsztos üregei.

A nagylengyeli olaj 0,9 feletti, 0,95-0,98t/m³ súrúségú, igen viszkózus nehézolaj, amely igen kevés könnyű, benzinrészt tartalmaz. Az olajnak csak 35-50\%-a szénhidrogén, a többi kén-, oxigén- és nitrogénatomokat is magában foglaló gyanta és aszfaltén. A nagylengyeli olajnak ez a karaktere nem a mikrobiális múködés, a biodegradáció következménye, hiszen teljes és érintetlen normál-alkán sorozattal rendelkezik a gázkromatográfiás mérések eredményei szerint (ClAYTON \& KonCZ 1994). A nagylengyeli olaj kéntartalma nagy (2-6\%), ami arra utal, hogy az olaj karbonátokban gazdag kőzetben képződött. Oxigénhiányos tengeri üledékképződés során a szulfátredukáló mikrobák kénhidrogént termelnek, ami a fémekben szegény karbonátos üledékekben nem tud megkötődni fémszulfidok, például pirit formájában (GRANSCH \& POSTHUMA 1974). Így a kénhidrogénből a kén a szerves anyagba, a kerogénbe épül be, ami létrehozza a kénben dús, IIS típusú kerogént, amelyben a szerves kén és szén atomaránya legalább 0,04 (ORR 1986). Ennek a kénben gazdag kerogénnek a hőbomlása eredményezi a kénben gazdag nehézolajat, amikor az anyakőzet az üledékek lerakódása során egyre mélyebbre és nagyobb hőmérsékletű környezetbe kerül.

$\mathrm{Az}$ anyakôzetek extraktumaiban és az olajokban lévő szénhidrogének tulajdonságainak összehasonlításán alapuló olaj-anyakőzet korrelációk eredményei szerint a nagylengyeli olaj anyakőzete a Kösseni Formáció (KonCZ 1990, 2016; ClAyTON \& KonCZ 1994). A késố triász korú Kösseni Formációból, a késő kréta korú Jákói Márgából és a középső miocén korú badeni anyakőzetekből előállított extraktumok szénhidrogénjeinek összehasonlítása, az anyakőzet-anyakőzet korreláció arra az eredményre vezetett, hogy a Kösseni Formáció szénhidrogénjei különböztek a többi anyakőzetekéitől. A felsô kréta és a középső miocén anyakőzetek szénhidrogénjei tulajdonságaikban nem különültek el egymástól. A Kösseni Formáció szénhidrogénjei izotóposan könnyebbek voltak, és - értelemszerúen - nem tartalmaztak oleanánt. Ez utóbbi, a szárazföldi zárvatermő növényzetből származó oleanán csak a felsô kréta idôszaktól kezdődően létezik (PETERS \& MoLDOwAN 1993). A nagylengyeli nehézolaj szénhidrogénjei izotóposan könynyebbek voltak, továbbá oleanánt nem tartalmaztak, szemben a fooleg miocén tárolókőzetekben felhalmozódott olajokkal, amelyek izotóposan nehezebbek voltak, és oleanánt tartalmaztak. Bár az olajok desztillációs frakcióinak jellege nem tekinthetô általános érvénnyel genetikai információhordozónak, a kösseni eredetű nagylengyeli olaj párlataiban parafin, a többi olaj párlataiban intermedier, nafténesbe hajlónak bizonyult (GRÁF 1961).

A Kösseni Formáció a dunántúli-középhegységi szerkezeti egység nyugati részén fejlődött ki. A Bakonyban, a Keszthelyi-hegységben felszínközelben, a Zalai-medence aljzatában mélyen a fiatalabb üledékek alatt ismert. Vastagsága 20-400 m között változik: a Zalai-medencében és a Dunántúli-középhegység Ny-i részén a legnagyobb, és kelet felé a Dachsteini Mészkő Formációval összefogazódik, majd kiékelődik (HAAS 1998). Az ősföldrajzi rekonstrukció szerint a Dunántúli-középhegység a Tethys óceán Ny-i részén, az Északi- és a Déli-Alpok között helyezkedett el (1. ábra) (HAAs et al. 1995). A dunántúli-középhegységi kösseni medencerész ősföldrajzi-fejlődéstörténeti tendenciái összhangban vannak a Déli-Alpokban és az Északi-Mészkőalpokban észlelt tendenciákkal: közéjük a középhegységi szegmens ellentmondásmentesen beilleszthető (HAAs 1993). Az említett eredeti ősföldrajzi helyzetből a középhegységi elem keleti irányban mozdult el, és jelenleg az Ausztroalpi- és a Tiszai-egység között helyezkedik el (2. ábra) (HAAs et al. 1995).

A Kösseni Formáció rétegtani megfelelője ÉszakOlaszországban, Lombardiában a Riva di Solto Formáció, amely a Lugano-tótól a Garda-tóig terjed, és legtöbbször már a felszínen is mutatkozik. Ennek a Lombardiai-medencének az északi szomszédja volt a Dunántúli-középhegység elem. A felső triász időszaki üledékképződés a tektonikai hatások miatt blokkokra tagolódott medence egyes részmedencéiben ment végbe, amelyeknek eltemetődési története igen különbözô volt aszerint, hogy - egyrészrôl milyen mértékú volt a felső triász idôszaki üledékképződés, másrészről milyen vastag jura képződmények rakódtak le a későbbi inverziót megelőzően. Ezek a hatások azt eredményezték, hogy az egyes részmedencék jelenleg felszínen lévő Riva di Solto Formációja igen eltérő termikus érettséget ért el. A részmedencék közül a Lugano Platform és az Albenza terület Riva di Solto Formációjának vitrinitreflexióval kifejezett termikus érettsége $0,3 \%$, illetve $0,3-$ 0,5\%, azaz termikus értelemben éretlen (STEFANI \& BURCHELL 1990). A többi részmedencében a termikus érettség $1,0 \%$ feletti vitrinitreflexióval jellemezhető. A legmagasabb termikus érettség az Iseo részmedencében volt mérhető: a vitrinitreflexió átlagosan 4,0\% volt. Ez az igen magas érték annak következménye, hogy az eleve legalább 2000 méter vastagságú Riva di Solto Formációt vastag jura képződmények fedték be a részmedence későbbi inverzióját megelőzően. Saját mintagyûjjtésünk és méréseink hasonló tendenciákat mutattak (BALÁzs \& Koncz 1999). A Keszthelyihegységben mélyült Rezi-1 fúrásban a Kösseni Formáció szerves anyagának termikus érettsége felszínközelben (max. 300 m) igen alacsony. A Rock-Eval mérésekból származó és a termikus érettségre jellemző $\mathrm{T}_{\max }$-értékek átlaga $411{ }^{\circ} \mathrm{C}$. A Lugano-platform területén a Riva di Solto $0,3 \%$ vitrinitreflexióval jellemezhető.

Milano közelében nagy méretû és készletû gáz-gázkondenzátum felhalmozódást fedeztek fel. Ennek a Malossa elnevezésű előfordulásnak a tárolókőzetei korukat illetően a felsô triász Fődolomittól az alsó krétáig terjednek, és 5150_ 5670 m mélységben helyezkednek el (MATTAVELLI \& MARGARUCCI 1979). A genetikai korrelációk eredményei szerint a Malossa-mező szénhidrogénjei a Riva di Solto Formációban képződtek (RIVA et al. 1986). A Malossa-mező szénhidrogénjeinek szénizotóparányai izotóposan könnyú karaktert mutatnak, hasonlóan a Magyarország területén 


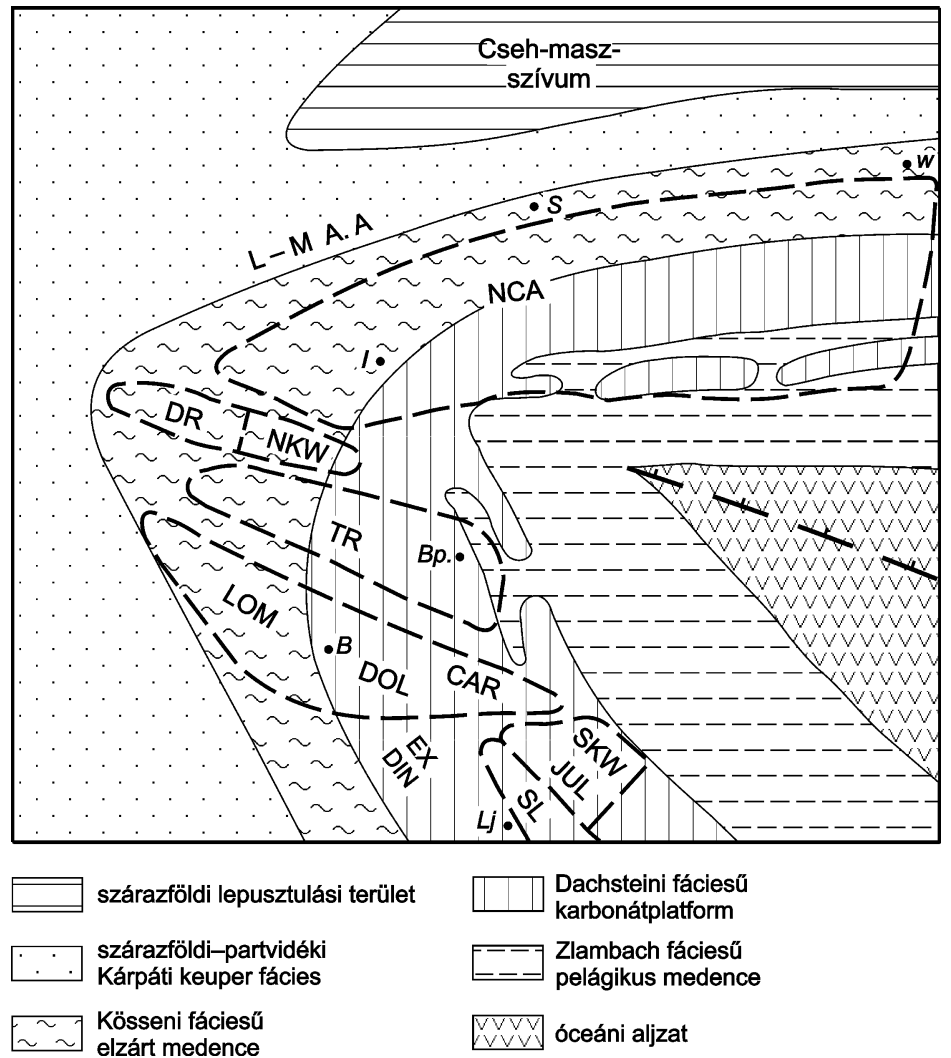

1. ábra. Fácieseloszlás a középső noriban (HAAS et al. 2009 alapján)

CAR - Kárpátok, DOL - Dolomiok, DR - Dráva-gerinc, EX DIN - Külső-Dinaridák, JUL - Juliai Alpok, LOM - Lombardia,NCA - Északi-Mészkőalpok, NKW - Északi-Karavankák, SKW - DéliKaravankák, SL - Szlovén-medence, TR -Dunántúli-középhegység

Figure 1. Facies distribution for the latest middle Norian (after HAAS et al. 2009)

CAR - Carpathians, DOL - Dolomites, DR - Dráva Range, EX DIN - External Dinarides, JUL - Julian Alps, LOM - Lombards, NCA - North Calcareous Alps, NKW - North Karawankas, SKW - South Karawankas, SL - Slovenian Basin, TR -Transdanubian Range

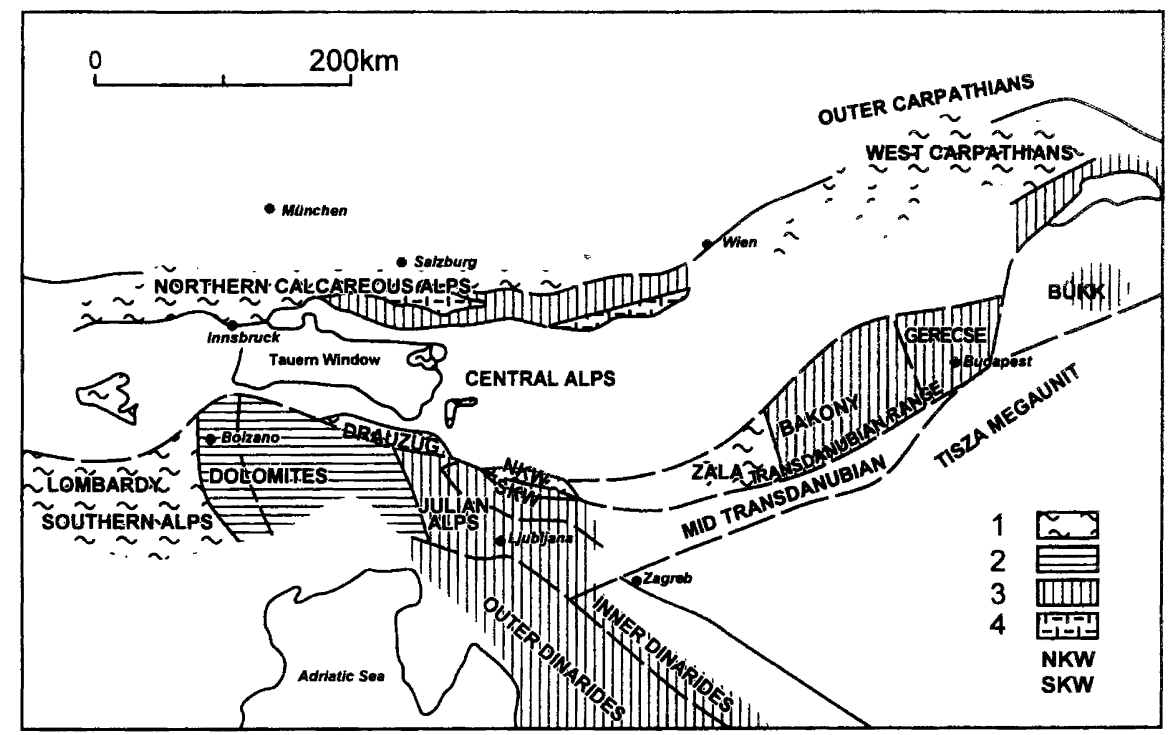

2. ábra. A nori-rhaeti fácieszónák jelenlegi helyzete

1 - Kösseni fácies, 2 - Dachsteini Dolomit, Fődolomit, 3 - Dachsteini Mészkő, zátonyképződmény, 4 - Zlambach fácies, NKW - Északi-Karavankák, SKW - Déli-Karavankák (HAAS et al. 1995 után)

Figure 2. Present-day setting of norian-rhaetian facies zones

1 - Kössen facies, 2 - Dachstein Dolomite, Dolomia Principale, 3 - Dachstein Limestone reefs, 4 - Zlambach facies, NKW - Northern Karawankas, SKW - Southern Karawankas (after HAAS et al. 1995) 
lévő Kösseni Formációhoz és a belőle képződött nagylengyeli olajhoz. Mivel a Malossa területen hiányzik a Riva di Solto Formáció, feltételezhetô, hogy a szénhidrogének anyakőzete a Malossa-mezó északi szomszédságában lévő Iseo-medence keleti részén van, ahol a Riva di Solto Formáció igen nagy vastagságban fejlődött ki, és a jura időszakban került abba az állapotba, hogy szénhidrogéneket tudjon generálni.

\section{A Kösseni Formáció tulajdonságai a Rezi-1 fúrásban}

A Rezi-1 fúrásban a Kösseni Formáció mélységintervalluma 24-265 m, amelyben három egység különíthetô el a kőzetek típusa szerint (HAAs 1993): 265-201, 201-73 és 7324 m. Hasonló egységek szerepelnek a Rock-Eval eredményeket közlő publikációban (HETÉNYI 1989). Az alsó rész (196-265 m) 60\%-nál nagyobb kalcium-karbonát tartalmú mészmárga, a középső rész agyagmárga és a felső rész aleurolit. A következőkben a geokémiai paraméterek trendjei kerülnek bemutatásra. A trendek a ,mozgó átlag” módszerével (Kriging) készültek, amelynek során a mélység növekedésének megfelelő öt adat mediánja jellemzi az illető szakaszt (DAVIS 1986).

\section{Az S2 és TOC adatok trendjei}

Az S2 (mg CH/g kőzet) és a TOC (\%) adatok a RockEval elemzésekből származnak (HETÉNYI 1989). Az S2 a kőzet szénhidrogén-potenciálja, amely azt jelzi, hogy mennyi szénhidrogén képes keletkezni akkor, ha a kőzet szerves anyagának megfelelő, aktív része teljes mértékben átalakul szénhidrogénekké. A TOC a szerves széntartalom.
Mind az S2 , mind a TOC trendértékek 123-176, illetve 212$252 \mathrm{~m}$ intervallumban egy-egy maximummal rendelkező szakaszt mutatnak (3. ábra). A kisebb mélységben lévő szakaszban 150-152 m mélységben az S2 31, a TOC 6,1 maximumot ér el. A nagyobb mélységben lévő szakaszt mindkét paramétert illetően két maximum jellemzi: az S2 trendértékek 216-217, illetve $241 \mathrm{~m}$-ben 52, illetve 48 S2 maximumot, a TOC trendértékek 214, illetve 241-250 mben 6,6 maximumot mutatnak. Az S2 és TOC adatok ciklikus változásai összhangban lehetnek a tengerszintingadozásokkal (HETÉNYI \& SAJGó 2004). Tekintettel arra, hogy a termikus érettség igen alacsony fokozatú, a mért szénhidrogénpotenciál-értékek (S2) a Kösseni Formáció eredeti potenciálját mutatják.

\section{A HI és S/C adatok trendjei}

A hidrogénindex (HI mg CH/g TOC) a kerogén minőségét jelzi. Az 50-157 m szakaszban a HI trendadatok 50-től 500 fölé emelkednek, de a 600 értéket még nem érik el. 212217 m intervallumban a HI-értékek 700 felettiek, továbbá a 227-254 m szakaszban 600 felettiek, de a 700 értéket nem érik el (4. ábra). A trendadatokból látható, hogy a kerogén minősége a mélység növekedésével egyre nagyobb mértékben olajgeneráló.

A szerves kén és szén atomaránya (S/C) 200 métertől kezdődően 0,04 feletti, és ennél fogva a kénben dús, IIS típusú kerogén jelenlétét jelzi (VETŐ et al. 2000) (4. ábra). $\mathrm{Az}$ említett szakaszban (>200 m) a kőzetek karbonáttartalma $60 \%$ feletti, kisebb mélységben viszont $20-60 \%$ közötti, lényegesen alacsonyabb.

Az előzőekben ismertetett trendadatok szerint a Rezi-1 fúrásban feltárt Kösseni Formáció alsó (>200 m) szakasza mind mennyiségi (S2, TOC), mind minőségi (HI, S/C)
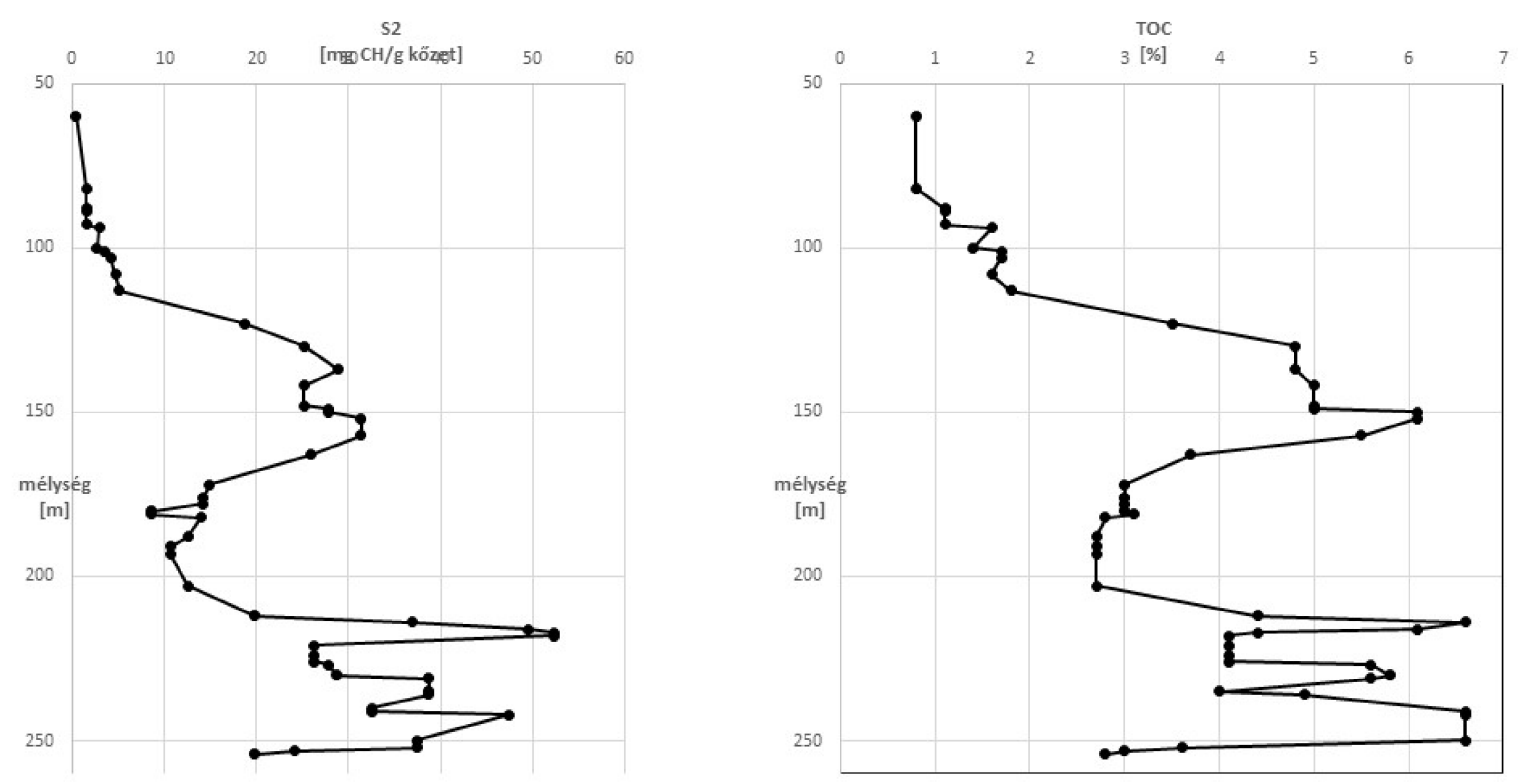

3. ábra. S2 és TOC trendek a Rezi-1 fúrásban

Figure 3. $S 2$ and TOC trends in Rezi-1 drilling (mélység = depth in metre, közet = rock) 

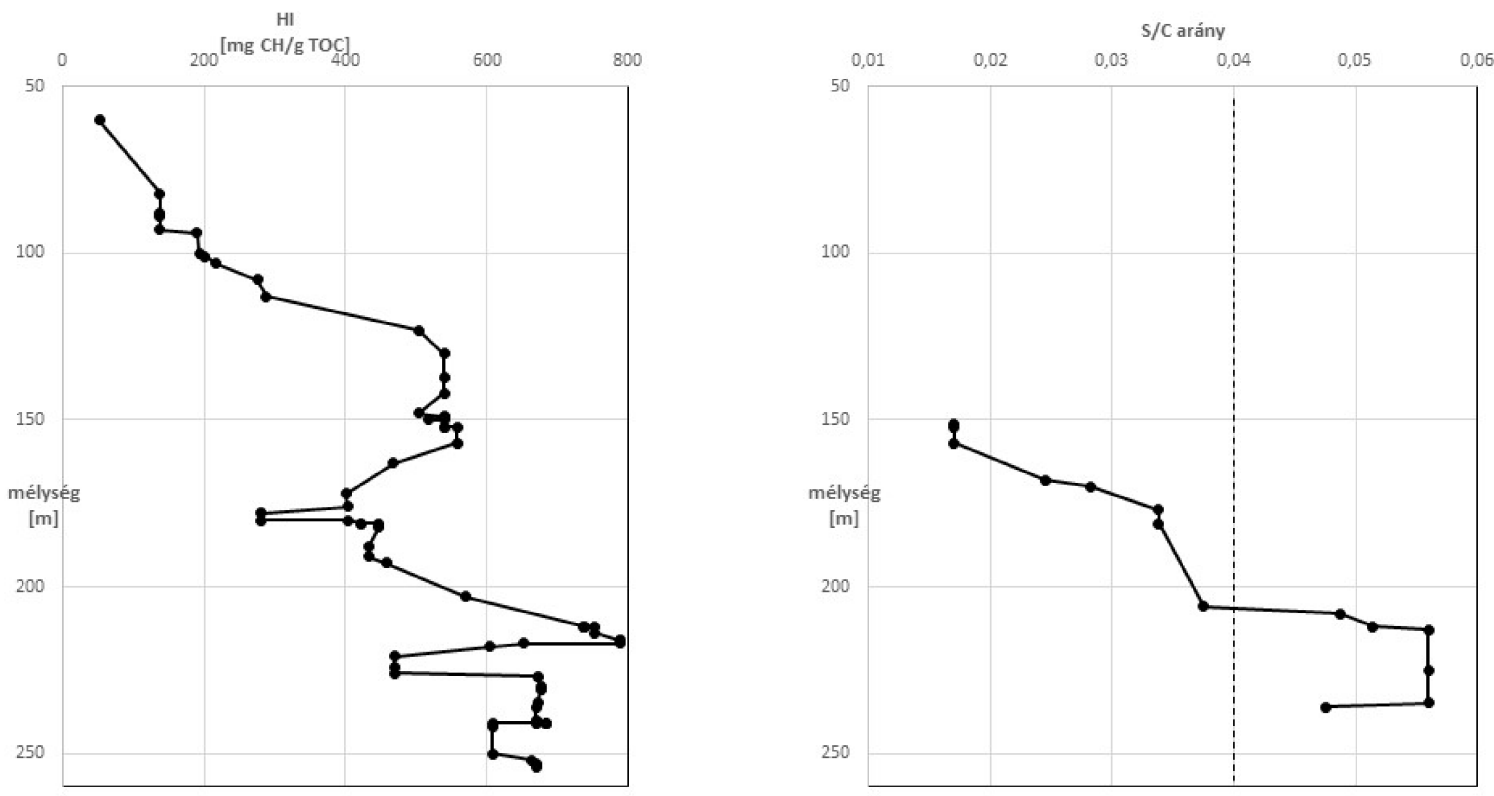

4. ábra. HI és $\mathrm{S} / \mathrm{C}$ trendek a Rezi-1 fúrásban

Figure 4. HI and S/C trends in Rezi-1 drilling (mélység - depth in metre, arány - ratio)

szempontból a legkedvezőbb tulajdonságokkal rendelkezik az olajképződést illetően. Itt a kerogén típusa kénben dús (IIS), amelyre jellemző, hogy termikus hatásra ,bomlékonyabb", mint a kénben szegényebb (II) típus. Ennek oka az, hogy a C-S kötések felbomlásához szükséges energia kisebb, mint a C-C kötésekéhez szükséges. Ennek következménye az, hogy még a 0,4\% vitrinitreflexiónak megfelelő termikus érettséget sem kell elérnie ahhoz, hogy meginduljon az olajképződés (BASKIN \& PETERS 1992). Ezzel szemben a II típusú kerogén esetében az olajképződés megindulásához legalább 0,6\% vitrinitreflexiónak megfelelő termikus érettség szükséges.

\section{A Kösseni Formáció szerves anyagának termikus átalakulási folyamata}

A szerves anyag hőbomlásának leírására az Arrheniustörvény alkalmas, amely a reakciósebesség (k) és az abszolút hőmérséklet (T Kelvin-fok) közötti kapcsolatot fejezi ki (COMER 1992):

$$
\ln \mathrm{k}=-\mathrm{E} / \mathrm{RT}+\ln \mathrm{A}
$$

Az aktiválási energia ( $\mathrm{E} \mathrm{kcal} / \mathrm{mol}$ ) azt a minimális energiát jelenti, amely ahhoz szükséges, hogy a kémiai kötés az egyes atomok között fel tudjon bomlani. Az „A” tényező a frekvenciafaktor (millió év ${ }^{-1}$ ). Az egyenletből (1) látható, hogy azonos frekvenciafaktor esetén a hőmérséklet növekedésével a reakciósebesség exponenciálisan nő.

A fent említett kinetikai állandók (E, A) meghatározására szolgáló módszerek egyikének az azonos hômérsékleten végzett (izoterm) kísérletek tekinthetők, amelyeket több hőmérsékleten hajtanak végre. A kísérleti eredmények egy $\ln \mathrm{k}-1 / \mathrm{T}$ diagramban az Arrhenius-törvény szerint egyenest adnak, amelynek meredekségéből az aktiválási energia, tengelymetszetéből pedig a frekvenciafaktor logaritmusa határozható meg.

Az izoterm kísérletek tulajdonképpen a pirolízis körébe tartoznak, amelyek során a természetesnél nagyobb hőmérsékleten tartják a vizsgálandó kőzetet azért, hogy a reakciók idejét lerövidítsék, továbbá inert gázt használnak.

A Monterey Shale vizes pirolízise során meghatározott kinetikai konstansok alkalmasak lehetnek a Kösseni Formáció alsó részén (> 200 m) lévő IIS típusú kerogén termikus átalakulásának számítására (LEWAN 1989). Az említett kinetikai konstansokat COMER (1992) cikkében találtam meg. Választásom azért is esett LEWAN vizes pirolízissel nyert eredményeire, mert a víz jelenléte a természetes közeget alkotja. A víz poláris, dipólus-momentummal rendelkező vegyület lévén elősegíti a kerogén bomlását. A többi adat száraz (víz) nélküli körülmények között született. Kaliforniában ismert a miocén Monterey Shale, amelynek szerves kén és szén atomaránya 0,044. A belóle képződött olaj magas kéntartalmú nehézolaj, amely alacsony hőmérsékleten keletkezett igen alacsony termikus érettség elérésekor. A kísérletek eredményeiből meghatározott kinetikai konstansok számszerú értékei: E 34,3 kcal/mol, ln A 48 (millió év ${ }^{-1}$ ). A Rezi-1 fúrásból, 142 m mélységből vett kőzetmintából pirolízissel meghatározott kinetikai konstansok: E 49,0 kcal /mol, ln A 61 (millió év $\left.{ }^{1}\right)$. A mélységérték alapján megállapítható, hogy a pirolízisnek alávetett kôzet II típusú kerogént tartalmazott, és felhasználható a Rezi-1 fúrás Kösseni Formációja szerves anyagának jellemzésére 200 méternél kisebb mélységben. Ez utóbbi kinetikai konstanspárt a USGS denveri laboratóriumában határozták meg a Lawrence Livermore Kinetics (LLNL) program segítségével.

A szerves anyag (kerogén) termikus átalakulásának számítását izoterm viszonyok között, kinetikailag elsőrendú 
reakció esetén a következő összefüggés teszi lehetővé (COMER 1992):

$$
\ln \left(\mathrm{c}_{\mathrm{o}} / \mathrm{c}_{\mathrm{t}}\right)=\mathrm{k} \times \mathrm{t}
$$

A reakciósebesség $(\mathrm{k})$ és az idő $(\mathrm{t})$ szorzata megadja a kezdeti koncentráció $\left(\mathrm{c}_{\mathrm{o}}\right.$ ) és a $\mathrm{t}$ idő elteltével lecsökkent koncentráció $\left(\mathrm{c}_{\mathrm{t}}\right)$ hányadosának logaritmusát. A kinetikailag elsőrendú reakció esetén nem szükséges a molekulák összeütközése, hanem maga a molekula, ez esetben a kerogén bomlik részekre.

Az üledékes kőzetek szerves anyaga azonban nem izoterm körülmények között alakul át például olajjá és gázzá, hanem az üledékképződésnek megfelelően egyre emelkedő hőmérsékleten. Ennek megfelelően a kérdéses képződmény idő-mélység, illetve idô-hômérséklet összefüggését izoterm szakaszokra bontjuk - például 10 Celsius fokonként emelkedő hômérséklet-sorozathoz rendeljük a hozzájuk tartozó időtartamokat. Így az egyes izoterm szakaszokra alkalmazott, (1) egyenlettel kiszámított reakciósebességet szorozzuk az izoterm szakaszokhoz tartozó időtartamokkal a (2) egyenlet szerint. Feltételezve a $c_{o}$ bármilyen értékét, a lecsökkent koncentráció $\left(\mathrm{c}_{\mathrm{t}}\right)$ számítható:

$$
\ln c_{t}=\ln c_{o}-k \times t
$$

Mivel a keletkezett termék koncentrációja $\left(\mathrm{c}_{\mathrm{k}}\right)$ számítható a $c_{\mathrm{o}}-\mathrm{c}_{\mathrm{t}}$ különbségból, az átalakulási vagy transzformációs arányszám $\left(\mathrm{TR}=\mathrm{c}_{\mathrm{k}} / \mathrm{c}_{\mathrm{o}}\right)$ is megadható, ha az egyes izoterm szakaszokban végbement átalakulásokat összegezzük.

Az egyes izoterm szakaszokhoz tartozó időt a Kösseni Formáció eltemetődési története szolgáltatja, amely a 830 m vastagságúnak feltételezett Kösseni Formáció feküjére vo- natkozik a Bak-Nova-árok helyzetében (5. ábra) (CLAYTON \& KonCZ 1994). $42{ }^{\circ} \mathrm{C} / \mathrm{km}$ geotermikus gradiens és $10^{\circ} \mathrm{C}$ felszíni hőmérséklet esetén a 10 Celsius fokonként számított izoterm szakaszok vastagsága $240 \mathrm{~m}$. A jelenlegi geotermikus gradiens alkalmazására azért került sor, mert nem találtam olyan hőáramadatokat, amelyek a neogén előtti időszakra nézve mérvadóak lehettek volna. A reakciókinetikai számításokban a 10 Celsius fokos izoterm szakaszokhoz tartozó hőmérsékletként az aktuális hőmérsékletintervallum középértékét használtam: például 10 és $20^{\circ} \mathrm{C}$ közöttinél $15^{\circ} \mathrm{C}$, és így tovább. A feltételezett eltemetődési történetből látható, hogy a Kösseni Formáció feküje jelenleg 5390 m mélységben lehet. Továbbá, a felső triász (T3), jura (J) és alsó kréta (K1) üledékképződést az ausztriai (A), a felső krétáét (K3) a larami (L), a paleogénét $(\mathrm{Pg})$ a pireneusi $(\mathrm{P})$ orogén fázis szakította meg.

Az (1) egyenlet szerint a reakciósebesség (k) számításához az aktiválási energia (E) és a frekvenciafaktor (A) ismerete szükséges. A Kösseni Formáció szerves anyagának termikus átalakulására a következő, előbbiekben említett kinetikai konstansok lehetnek jellemzőek, amelyek a miocén korú Monterey Formáció kerogénjére vonatkozóan állnak rendelkezésre: E 34,2 kcal/mol, ln A 48 millió év ${ }^{-1}$ (COMER 1992, LEWAN 1989). Ezt a választást az előzôekben megindokoltam. A modellszámítások eredményeihez tartozóan említem meg, hogy a számított vitrinitreflexiók jól megközelítik a mérteket: 2500 m mélységben 0,6\%, 3000 m mélységben 0,8-1,0\% (CLAYTON \& KonCZ 1994).

A 6. ábra IIS jelű görbéje szemlélteti a kinetikai számítások eredményeként előállított átalakulási mértéket

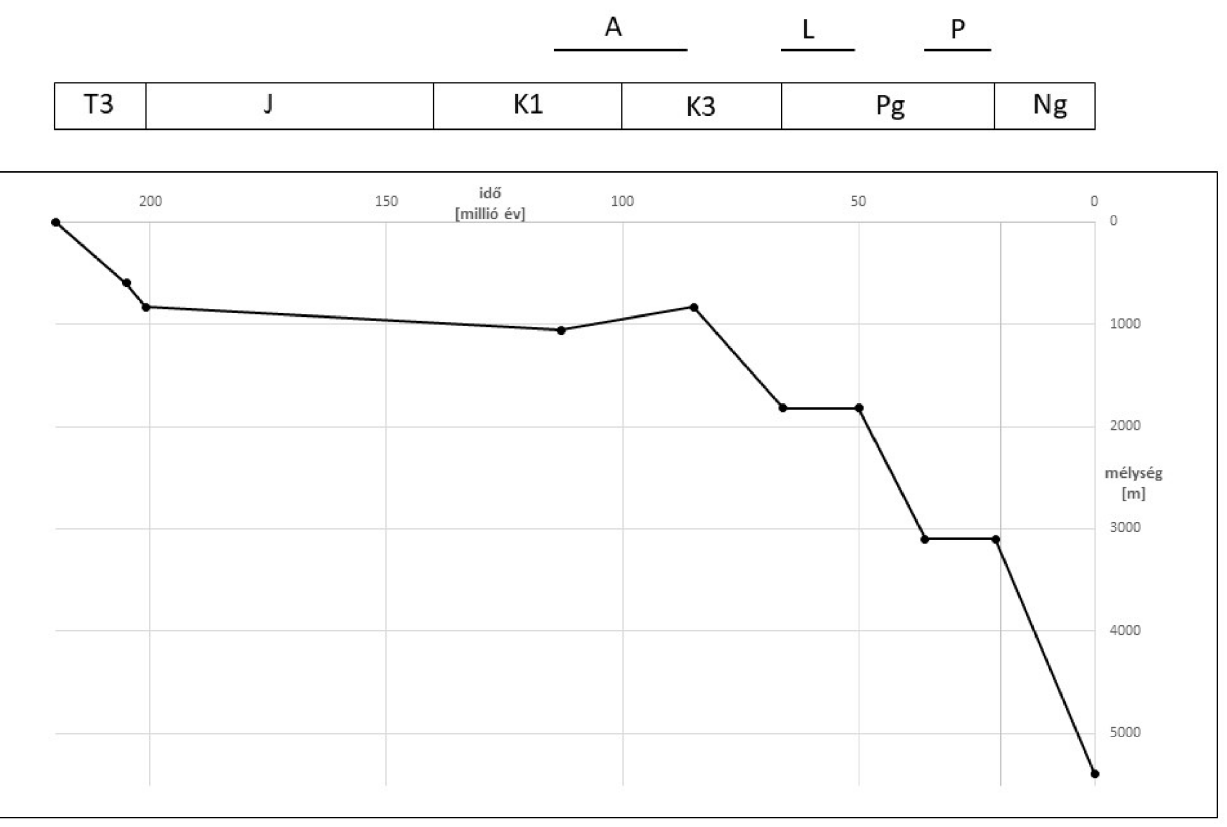

5. ábra. A Kösseni Formáció eltemetődési története a Bak-Nova-árokban

T3 - felső triász, J - jura, K1 - alsó kréta, K3 - felső kréta, Pg - paleogén, Ng - neogén, orogén fázisok: A - ausztriai, L - larami, P pireneusi

Figure 5. Burial history of Kössen Formation in Bak-Nova trench

T3 - Upper Triassic, J - Jurassic, K1 - Lower Cretaceous, K3 - Upper Cretaceous, Pg - Palaeogene, Ng - Neogene, orogenic events: A Austrian, $L$ - Laramide, $P$ - Pyrenean (idö = time in million years, mélység = depth in metre) 
(TR\%) az idő függvényében. Ennek alapján a Kösseni Formáció kerogénjének nehézolajjá alakulása a jura időszak végén, az alsó kréta időszak kezdetén kezdődik, és a felsô kréta időszakban már gyakorlatilag be is fejeződik. A teljes mértékú átalakulás 50 és 70 ${ }^{\circ} \mathrm{C}$ hőmérséklet-intervallumban, 950-1460 m mélységben ment végbe. Ennek a korai, viszonylag alacsony hőmérsékletet igénylő képződésnek az oka egyrészrôl az, hogy a Kösseni Formáció kerogénje IIS típusú, amely termikus értelemben bomlékonyabb. Másrészről az említett intervallumhoz tetemes idô, mintegy 81 millió év tartozik a 154-73 millió év intervallumban.

Összehasonlításul elvégeztem a kinetikai számításokat a Rezi-1 fúrás Kösseni Formációjának azon részére, amely csak II típusú kerogénnel rendelkezik. Itt a kinetikai konstansok a következők: E 49,0 kcal/mol, $\ln$ A 61 millió év ${ }^{-1}$. Az eredményeket a 6 . ábra II jelú görbéje szemlélteti. Látható, hogy az olaj képződése az eocén időszakban kezdődött, és a neogén elején fejeződött be. Ez azt jelenti, hogy az olajképződés a II típusú kerogén esetében 2-3 km mélységintervallumban, 95-135 ${ }^{\circ} \mathrm{C}$ hômérsékleten mehetett végbe. Tehát, jóval mélyebben és magasabb hőmérsékleten, mint a kénben dús és nehézolajat létrehozó IIS típusú kerogén esetében. Az a tény, hogy Nagylengyel térségében csak nehézolaj halmozódott fel, arra utal, hogy a Bak-Novaárokban mint depocenterben a generáló anyakőzet kerogénjének típusa kénben dús volt, és a II típusú kerogént tartalmazó rész, amely a Rezi-1 fúrás kisebb mélységű részében mutatkozott, nem jött létre az üledékképződés során a Bak-Nova- árokban.

Kiszámítható a Kösseni Formáció feküjéhez rendelt, feltételezett eltemetődés-történet mentén a szerves anyag érettségét mutató vitrinitreflexió (SWEENEY \& BURNHAM 1990). Eszerint a Kösseni Formációban a nehézolaj képződése a vitrinitreflexió 0,36-0,42\% tartományában ment végbe (7. ábra). Ez jóval alacsonyabb érettség, mint a kőolajképződés kezdetének tekinthető $0,6 \%$ vitrinitreflexió a kevésbé bomlékony II típusú kerogén esetén. Ennek az eltérésnek az oka a bomlékonyabb, kénben dús, IIS típusú kerogén, amely a Kösseni Formáció alsó részére jellemző a Rezi-1 fúrásban. Az olaj-szénhidrogének képzôdését követően nehézolaj egészen addig változatlan marad, amíg a nehézolaj aszfalténjeinek hőbomlása meg nem kezdődik. A nehézolaj primer migrációja a Bak-Nova-árokban akkor következhetett be, amikor a Kösseni Formáció feküje 30003100 m mélységben volt az eocén idején (36-37 millió év).

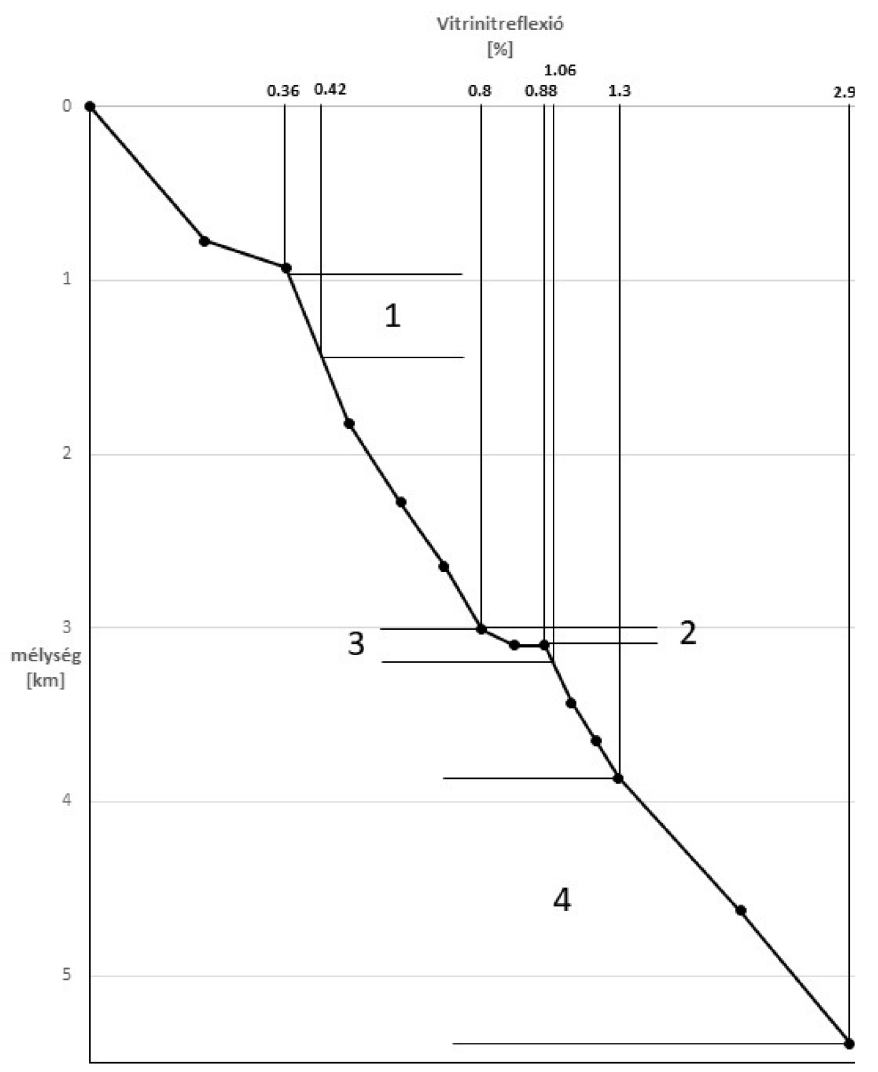

7. ábra. A Kösseni Formáció vitrinitreflexiójának változása a mélységgel $\mathrm{R}_{0} \%$ - vitrinitreflexió, 1 - nehézolaj képződése IIS típusú kerogénből, 2 - a nehézolaj primer migrációja, 3 - aszfalténbomlás, 4 - gázképződés

Figure 7. Vitrinite reflectance of Kössen Formation vs. depth

$R_{0} \%$ - vitrinite reflectance, 1 - heavy oil generation from IIS type kerogen, 2 - primary migration of heavy oil, 3 - asphaltene decomposition, 4 - gas generation). (mélység = depth) 
Ugyanis a nagylengyeli fúrások nehézolajainak termikus érettsége $0,80-0,88 \%$ vitrinitreflexiónak megfelelő a metilfenantrén-index alapján. Az olajok termikus érettségének vitrinitreflexió egyenérték formájában történő számszerú megadására az aromás szénhidrogének közül a metilfenantrének alkalmasak (RADKE \& WELTE 1983).

\section{A nehézolaj termikus átalakulásának folyamata}

Kísérleti bizonyíték van arra, hogy a kőolaj aszfalténjei átalakulhatnak olaj-szénhidrogénné (ORR 1986). Az említett szerzô a Monterey Formációban képződött olajmintát $300{ }^{\circ} \mathrm{C}$ hőmérsékleten tartotta 11000 órán keresztül, és eközben megfigyelte az olajban bekövetkezett változásokat. Az eredetileg 0,999 t/m³ sûrúségú, 24,6\% aszfalténtartalmú nehézolaj a kísérlet végeztével $0,835 \mathrm{t} / \mathrm{m}^{3}$ sûrûségű, 2,4\% aszfalténtartalmú könnyű olajjá alakult. A nehézolaj átalakulása könnyú olajjá az aszfalténtartalom csökkenéséből eredt. Ez érthető is, mert az aszfaltének termikusan sokkal bomlékonyabbak az olaj-szénhidrogéneknél.

Az aszfaltének hőbomlásának kinetikai állandói a következők (PRIMIO 2000): E $52 \mathrm{kcal} / \mathrm{mol}$, ln A 61 millió év $^{-1}$. ORR kísérleti eredményeit jól megközelítő adatokat szolgáltattak az említett kinetikai állandók. Az összehasonlítás eredményét a 8. ábra mutatja be, ahol a korábbiakban közölt (2) egyenlet logaritmikus alakja szerepel:

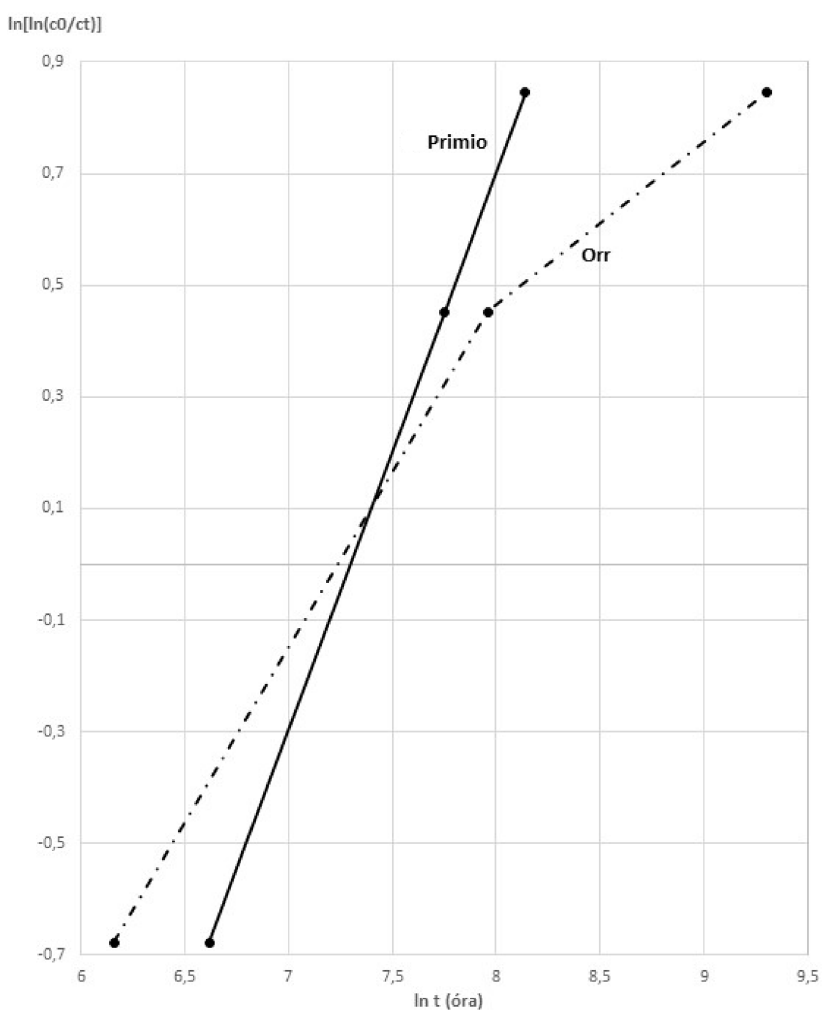

8. ábra. Az aszfalténbomlás kinetikája

Figure 8. Kinetics of asphaltene decomposition

$$
\ln \left[\ln \left(\mathrm{c}_{0} / \mathrm{c}_{\mathrm{t}}\right)\right]=\ln \mathrm{t} \text { (óra) }+\ln \mathrm{k}
$$

A Kösseni Formáció feküjének eltemetődési történetét (5. ábra) felhasználva és az aszfaltének hőbomlása kinetikai állandóit alkalmazva előállítható az aszfalténbomlást leíró átalakulási arány (TR\%) időfüggvénye (a 6. ábrán AS jelöléssel). Látható, hogy az aszfalténbomlás túlnyomó része (90\%-a) az eocén-oligocén idejére (37-20 millió év) esik, amikor a Kösseni Formáció 3000-3200 m mélységben volt, és a szerves anyag termikus érettsége 0,80 és 1,06\% közötti tartományt ért el (7. ábra).

Említésre méltó, hogy Nagylengyel térségében kösseni eredetû könnyú olajat ez ideig nem fedeztek fel. A BakNova-árok helyzetében a Kösseni Formáció jelentős gáztartalommal rendelkezhet a jelenlegi 4560-5390 m mélységben. Ez a gáz a Kösseni Formáció szerves anyagának termikus bomlásából származhat, hiszen a gázképződés intenzívvé válásához szükséges, legalább 1,3\% vitrinitreflexióval jellemzett termikus érettséget a Kösseni Formáció feküje már a jelent megelőzően 3860 m mélységben elérte. Nem tekinthető véletlennek tehát, hogy a Bak-Novaárok helyzetében lévő Kösseni Formáció a nem hagyományos gázelőfordulások körébe tartozik (BADICS et al. 2011).

\section{Következtetések}

A Rezi-1 fúrás profiljában, a Kösseni Formációban mind a mennyiségi (S2, TOC), mind a minőségi (HI, S/C) adatok trendje az alsó részben (>200 m) mutatja a legkedvezőbb értékeket. A szerves szén-kén atomarány ebben a szakaszban a kénben dús, IIS típusú kerogén jelenlétét jelzi, amelynek termikus átalakulása nehézolajat eredményez. Mivel Nagylengyelben a felhalmozódások csak nehézolajból állnak, feltételezhető, hogy a hozzá tartozó generáló medencerészben a Kösseni Formáció organikus fáciese teljes egészében a Rezi-1 fúrás Kösseni Formációja alsó részének megfelelő lehetett.

Az I. táblázat tartalmazza a Kösseni Formációban végbement folyamatok mélység, idő és termikus érettség adatait, amelyek a Bak-Nova-árok feltételezett eltemetődési történetére illesztett számítások eredményeként jöttek létre.

A kénben dús, IIS típusú kerogén termikusan bomlékonyabb a szintén olajgeneráló II típusúnál. Ennek megfelelően az olajképződés „hamarabb”, enyhébb termikus feltételek mellett megindul, és $1460 \mathrm{~m}$ mélységben, $70{ }^{\circ} \mathrm{C}$ hômérsékleten már be is fejeződik. Ebben a hőmérséklettartományban biodegradáció is végbemehetett, de a nagylengyeli nehézolaj gázkromatográfiás analíziseiből kitűnt, hogy biodegradációra utaló jelek nincsenek: a normálalkánok sorozata teljes és érintetlen (CLAYTON \& KonCZ 1994). A képződött nehézolaj olyan mértékben viszkózus, hogy a vízkiszorulásos primer migráció végbemenetele az akkor még jelentősebb áteresztőképességű anyakőzetek (pelitek) esetében kizárható.

A nagylengyeli nehézolaj primer migrációja nem véletlenül esik az aszfaltén-bomlás kezdeti szakaszára az 
I. táblázat. Termikus átalakulások a Kösseni Formációban Table I. Thermal transformations in Kössen Formation

\begin{tabular}{l|c|c|c|}
\hline \multicolumn{1}{c|}{ Folyamatok } & $\mathrm{z}(\mathrm{m})$ & $\mathrm{t}\left(10^{6} \mathrm{év}\right)$ & VRE \% \\
\hline 1. Nehézolaj képződés & $950-1460$ & $154-73$ & $0,36-0,42$ \\
\hline 2. A nehézolaj primer migrációja & $3000-3100$ & $37-36$ & $0,80-0,88$ \\
\hline 3. Aszfalténbomlás & $3000-3200$ & $37-20$ & $0,80-1,06$ \\
\hline 4. Gázképződés & $3860-5390$ & $14-0$ & $1,30-2,95$ \\
\hline
\end{tabular}

1 - heavy oil generation, 2 - primary migration of heavy oil, 3 - asphaltene decomposition, 4 - gas generation, $z$ - depth $(m), t$ - time (Myr), VRE\% - vitrinite reflectance equivalent.

olaj termikus érettségét jelző adatok szerint. Mivel az aszfalténbomlás kisebb sûrûségú olajat eredményez, feltételezhető, hogy a térfogatnövekedés által okozott túlnyomás-többlet repeszthette meg a Kösseni Formációt 30003100 m mélységben, ahol a pelitek igen alacsony áteresztôképessége már nem teszi lehetôvé a hézagtér fluidumainak elszivárgását: azaz a Kösseni Formáció a jelzett mélységben eleve túlnyomásos lehetett. Ismeretes, hogy a délkelet-alföldi mélyfúrásokban 2600 m mélységtől kezdődően a pelitek pórustere áramlási szempontból izolálódik, és a további üledékképzôdés során túlnyomásossá válik
(SzAlAy 1982, KonCZ 2021). Ez a mechanikai okokra visszavezethetô túlnyomás jelentôs mértékben megnövekedhet, ha a pórustérben a fluidum térfogata megnő (SWARBRICK et al. 2002). Ha feltételezzük, hogy a képződött nehézolaj sûrüsége olyan nagy, mint a Monterey olajé $\left(0,999 \mathrm{t} / \mathrm{m}^{3}, 1,001 \mathrm{~m}^{3} / \mathrm{t}\right)$, akkor a felhalmozódott, 0,95-0,98 $\mathrm{t} / \mathrm{m}^{3} \quad\left(1,020-1,053 \mathrm{~m}^{3} / \mathrm{t}\right)$ súrúségú (fajtérfogatú) nagylengyeli olaj 2-5\% térfogat-növekedést jelent. Ennek a térfogat-növekedésnek a hatása abban az esetben jelentôs, ha a pórustér olajtelítettsége számottevően nagy. A Kösseni Formációnak a Rezi-1 fúrásban észlelt nagy szénhidrogénpotenciálja és a kiváló minőségû, olajgeneráló típusú kerogénje miatt a pórustér nagy olajtelítettsége indokoltan feltételezhetô. Tekintettel arra, hogy az aszfalténbomlás során szénhidrogén-gázok képződnek, amelyek az olajban oldódva megnövelik annak térfogatát, a térfogat-növekedés az előzőleg említettnél nagyobb is lehet (ORR 1986).

A Kösseni Formáció kerogénjének termikus átalakulása gázképződéssel zárul 3860 m mélységtől kezdődően a BakNova-árok eltemetődési történetére illesztett számítások eredményei szerint, amikor a szerves anyag termikus érettsége meghaladja az 1,3\% vitrinitreflexiónak megfelelőt.

\section{Irodalom -References}

Badics B., Uhrin A., Vetô I., BARThA A. \& SAJGó Cs. 2011: Medenceközponti földgáz-előfordulás elemzése a Makói-árokban. Földtani Közlöny 141/1, 445-468.

BALÁzS, E. \& KonCZ, I. 1999: Contribution to thermal evolution of Southern Alps and paleogeographically adjacent areas based on vitrinite reflectance data. - Memorie di Scienze Geologiche 51/1, 119-128.

BASKIN, D. K. \& PETERS, K. E. 1992: Early Generation Characteristics of a Sulfur-Rich Monterey Kerogen. - AAPG Bulletin 76, 1-13.

Clayton, J. L. \& KoncZ, I. 1994: Petroleum Geochemistry of the Zala basin, Hungary. - AAPG Bulletin 78/1, 1-22.

COMER, J. B. 1992: Thermal Alteration. - The Society for Sedimentary Geology (SPEM), Geochemistry of Organic Matter in Sediments and Sedimentary Rocks (SC27). https://doi.org/10.2110/scn.92.27.0073

DAvis, J. L. 1986: Statistics and Data Analysis in Geology. - John Wiley \& Sons, Inc., New York - Chichester - Brisbane - Toronto Singapore.

DuBAY L. 1962: Az észak-zalai medence fejlődéstörténete a kőolajkutatások tükrében. - Földtani Közlöny 92/1, 15-30.

GrÁf, L. 1961: A dunántúli terület olajainak összetétele és keletkezésük. - Geologija Nefti i Gaza 2, Moszkva (orosz nyelven).

Gransch, J. A. \& Posthuma, J. 1974: On the origin of sulfur in crudes. - In: Tissot, B. \& Bienner, F. (eds): Advances in Organic Geochemistry. Pergamon Press, Oxford, 727-830.

HAAs J. 1993: A „Kösseni-medence” kialakulása és fejlődése a Dunántúli-középhegységben. - Földtani Közlöny 123/1, 9-54.

HAAS, J. 1998: A Dunántúli-középhegység triász képződményeinek rétegtana. - In: BÉRCzI I. \& JÁMBor Á. (szerk.): Magyarország geológiai képzódményeinek rétegtana. A MOL Rt. és a MÁFI kiadványa, Budapest, 225-244.

HaAs, J, Kovács, S., Krystyn, L. \& LeIN, R. 1995: Significance of Late Permian-Triassic facies zones in terrane reconstructions in the Alpine - North Pannonian domain. - Tectonophysics 242, 19-40. https://doi.org/10.1016/0040-1951(94)00157-5

HaAs, J., Pomoni-Papaioannou, F. \& Kostopoulou, V. 2009: Comparison of the Late Triassic carbonate platform evolution and Lofer cyclicity in the Transdanubian Range, Hungary and Pelagonian Zone, Greece. - Central European Geology 52/2, $153-184$.

HetÉnYI, M. 1989: Hydrocarbon generative features of the Upper Triassic Kössen Marl from W. Hungary. - Acta MineralogicaPetrographica (Szeged) 30, 137-147.

HETÉNYI M. \& SAJGó Cs. 2004: Kőolajképződés karbonátos kőzetben: szerves geokémiai esettanulmány. - Magyar Kémiai Folyóirat Összefoglaló közlemények 109-110/4, 183-191.

KonCZ, I 1990: Nagylengyel és környéke kőolaj-előfordulásainak eredete. - Általános Földtani Szemle 25, 55-82.

KonCZ, I. 2016: A nagylengyeli nehézolaj triász eredetének bizonyítékai. Bányászati és Kohászati Lapok-Bányászat - Köolaj és Földgáz 149/5-6, 2-5.

KonCZ, I. 2021: A szénhidrogének primer migrációja. - Földtani Közlöny 151/1,51-64. https://doi.org/10.23928/foldt.kozl.2021.151.1.51

LEWAN, M. D. 1989: Hydrous pyrolysis study of oil and tar generation from Monterey shale containing high sulfur kerogen. - American Chemical Society National Meeting Symposium on Geochemistry. 
Mattavelli, L. \& Margarucci, V. 1979: Malossa Field - Italy Po Basin, - In: Treatise of Petroleum Geology, Atlas of Oil and Gas Fields, Structural Traps VII, 119-133.

ORR, W. L. 1986: Kerogen/asphaltene/sulfur relationships in sulfur-rich Monterey oils. - Organic Geochemistry 10, $499-516$. https://doi.org/10.1016/0146-6380(86)90049-5

Peters, K. E. \& Moldowan, J. M. 1993: The Biomarker Guide. Interpreting Molecular Fossils in Petroleum and Ancient Sediments. Prentice Hall, Englewood Cliffs, New Yersey.

Primio, R. DI, Horsfield, B. \& GuZman-VegA, M. A. 2000: Determining the temperaure of petroleum formation from the kinetic properties of petroleum asphaltenes. - Nature 406, 173-176. HTTPS://DOI.ORG/10.1038/35018046

RadKe, M. \& Welte, D. H. 1983: The methylphenanthrene index (MPI): A maturity parameter based on aromatic hydrocarbons. Advances in Organic Geochemistry 1981, 504-512. https://doi.org/10.1016/0146-6380(86)90008-2

Riva, A., Salvatori, T., Cavaliere, R., Ricchiuto, T. \& Novelli, L. 1986: Origin of oils in Po basin, Northern Italy. - Organic Geochemistry 10, 391-400. https://doi.org/10.1016/0146-6380(86)90038-0

Stefani, M. \& Burchell, M. 1990: Upper Triassic (Rhaetic) Argillaceous Sequences in Northern Italy: Depositional Dynamics and Source Potential. - AAPG Studies in Geology SG30, 93-106.

Sweeney, J. J. \& Burnham, A. K. 1990: Evaluation of a Simple Model of Vitrinite Reflectance based on Chemical Kinetics. $-A A P G$ Bulletin 74/10, 1559-1570.

Swarbrick, R. E., Osborne, M. J. \& Yardley, G. S. 2002: Comparison of Overpressure Magnitude Resulting from the Main Generating Mechanisms. In: Huffman, A. R. \& Bowers, G. L. (eds): Pressure regimes in sedimentary basins and their prediction. AAPG Memoir 76, 1-12.

SZALAY Á. 1982: A rekonstrukciós szemléletű földtani kutatás lehetőségei a szénhidrogén-perspektívák előrejelzésében a DK-alföldi neogén süllyedékek területén. - Kézirat, kandidátusi értkekezés, MTA Budapest.

Vetô, I., HeténYi, M., HÁmor-Vidó, M., Hufnagel, H. \& HaAs, J. 2000: Anaerobic degradation of organic matter controlled by productivity variation in a restricted Late Triassic basin. - Organic Geochemistry 31, 439-452. https://doi.org/10.1016/S01466380(00)00011-5

Kézirat beérkezett: 2020. 12. 10. 